\title{
How Do Women Politicians Display Their Online Faith in Social Media? Case study: The Mayor of Bucharest, Gabriela Firea
}

\author{
Adina-Loredana DOGARU-TULICĂ, PhDc \\ Doctoral School in Communication Sciences \\ Faculty of Journalism and Communication Sciences (FJSC) \\ University of Bucharest, Romania \\ E-mail: tulica.loredana@gmail.com
}

\begin{abstract}
Considering the role of religion in post-communist Romanian society, the relation between politics and religion and the fast expansion of social media, this paper aims to investigate how a woman politician, namely the mayor of Bucharest, the capital city of Romania, uses social media to address religious messages. This paper also studied the online public's reactions and interactions to these messages. The research covers messages from Gabriela Firea's Facebook page, the mayor of Bucharest, and was conducted between the 1st of July and the 31st of December 2018 on quantitative criteria. Two main results emerged from this analysis. The first one is that the mayor of Bucharest uses religious messages to promote herself politically and to gain the sympathy of the electorate. The fact that her religious posts generated the greatest number of interactions contribute to attracting new fans and reward the existing ones. The second main finding of this study was that religious messages generate a large number of reactions and interactions. This paper is part of a wider research work that approaches the triad of feminism, social media (Facebook) and political communication from a multidisciplinary perspective, in order to achieve political performance.
\end{abstract}

Keywords: Political communication; Feminine political leadership; Facebook; Religion, Social media interactions. 


\section{Introduction}

The present paper explores how women politicians, in this case the mayor of Bucharest, use social networks, especially Facebook, to promote religious messages in order to attract sympathy and approval of voters towards the policies they are pursuing. The research focuses on the mayor of Bucharest as she is the first woman elected mayor of the capital city of Romania. Also, she is on the third place in the top of politicians with the highest number of fans on Facebook after two men - Klaus Iohannis, president of Romania, and Victor Ponta, former prime minister of Romania.

The link between social media and religion is a growing research theme in the last decade (Helland, 2005; Campbell, 2012; Faimau and Behrens, 2016), and the present work was born out of the need to pursue the way religion and politics coexist in virtual Romanian space. This paper brings a novelty in the Romanian research, as there are currently no papers on how Romanian politicians express their faith through Facebook. Also, religion in Romanian social media is not an explored territory. Recent works speak about media and religion in Romania (Surugiu, 2012), the role of media in promoting religious tourism in Romania (Cristea, Apostol, Dosescu, 2015) or religion and politics in Romania (Stan, Turcescu, 2007). So, the case study originates in a premiere on the Romanian political scene - Bucharest has since 2016 the first woman mayor, a mayor who uses many religious themes in the public life and in the online environment.

Heidi Campbell speaks in Internet and Religion (2011) about three waves of academic research about religion on the Internet. First-wave studies began in 1990 when religion could do almost anything on cyberspace, researches often utopian. The second wave, more realistic, has dealt with defining and comparing different religious online phenomena. Nowadays, the third wave explores religion online more collaborative, longitudinal and interdisciplinary.

The biggest social network ever, Facebook, contributes to more rapid propagation and a far greater impact of messages of any type, including religious ones. Most studies on digital religion focus on how representatives of different churches, cults or people close to religious groups express their faith online, not how other professional categories, such as political or administrative leaders promote their faith online (e.g., Campbell, 2004, Campbell, 2010; Lovheim, 2004). It is not uncommon for people to share their faith online or to publish messages about faith, since Facebook is a medium that facilitate mass distribution of religious ideas or activities (Helland, 2012). Considering the above, the present paper finds useful the study of how politicians display their faith online, in this case the mayor of Bucharest.

The objectives of the present study are to analyze how a woman politician, mayor Gabriela Firea, uses social media to promote her religious messages, and to quantify how the public of her Facebook page reacts at and interacts with religious posts. 


\section{Theoretical framework}

\section{Religion, politics and social media}

Even after the nineteenth-century researchers argued that religion would fade in importance in front of industrial society (Inglehart, Norris, 2004), the presence of religion in public and political space has been the subject of numerous scholars over time. But, first of all, how do we define religion? Many researchers have tried over the years to define the concept of religion. Religion can be understood from several perspectives: as theology and ethical code - from the perspective of a body of ideas and outlooks, the ecclesiastical 'Church' - as a type of formal organization, religious groups and movements - as a social group (Haynes, 2014, 4). Kirkpatrick (2005) speaks about religion as psychological attachment and Fox sees religion as a social institution or phenomenon which "strongly influences human behavior." (2018) After several scholars argued that religion is invented, manufactured and does not involve reality, Schilbrack argued that religion exists even is socially constructed (2010).

Religion and politics have been interconnected since Antiquity. As Jonathan Fox states in An Introduction to Religion and Politics: Theory and Practice, Second Edition, regarding the Mesopotamian, Babylonian, Persian, Greek and Roman Empires, religion was connected to all political institutions. Moreover, evidence of the connection between religion and politics also appears in the Old Testament, which recalls the times when the separation between state and religion does not exist (Fox, 2018, 1). Friedrich Wilhelm Nietzsche, in The Antichrist (1895), taking ideas from St. Paul - the author of the famous Letters (or Pauline Epistles) founder of the Catholic Church, a church that expands rapidly across Europe and not only - brings in the context of social existence the relationship between religion and politics, emphasizing the necessity, the obligation even, that the political sphere of society governs using the principles of morality.

The events of the past decades clearly show that religion is, and will continue to be, a major player in politics. In Religion and Comparative Politics, Anthony Gill (2001) stated that the study of religion and politics was relatively new because for long time in sociology and political science scholars considered religion increasingly irrelevant in social life. Theorists like Weber, Durkheim, and Marx believed that religion was a pre-modern relic, which will disappear with development of industrialization, urbanization, bureaucratization, and rationalization (Bellin, $2008,317)$. Weber also observed a link between different social categories and religious behavior. This "elective affinity" is also determined by the cultural environment, occupation, geographical area (Weber, 1998, 10).

However, religion is adapting with contemporary politics. Radu Carp rejects the idea of surrender and blind submission, which is not part of the rigors of a democratic approach. He argues that religion is accommodating politics as politics 
is accommodated in religion, but each retains its original meaning (Carp, 2013, 8). Religion is a public actor and, as such, religion participates at all political levels in the European countries. This statement is true for non-European societies also (Giorgi, Polizzi, 2014). The same authors speak about how religious institutions and church representatives openly express their political views and religious groups try to mobilize citizens in a certain political direction. So, not only religion is adapting to politics, but religion tries to influence politics.

Referring to the functions that religion has in today's world, Nicolas Tenzer lists: the intellectual and philosophical function, more precisely the way how man relates now to God, the socio-political function, the moral function or how citizens report their behavior to good and evil in society and, last but not least, the psychological function by which man gains the power to face the unknown (Tenzer, 1994, 491). Speaking about the functions of religion, we can not ignore the electoral one. Religion can influence voters' opinion, according to Johnstone (1975) as religious affiliation and indices of religiosity are correlated with voting patterns.

Richard Neuhaus stated in 1986 that religion is a matter between an individual and his God, and that religion has its place in the church and home, not in public space (Neuhaus, 1986). Nonetheless, there are research papers which reveals that in our times religious networks can facilitate volunteerism and civic engagement (McClure, 2015; Merino, 2013; Schwadel et al., 2015). Recent papers (Sakellariou, 2018) suggest that, for young people, religious social capital is transformed gradually into social capital. Social activism becomes more important for young people overtime and religious affiliation has a secondary role concerning young people's participation.

Concerning religion in Romania, a study of Pew Research Center (2017) shows that $95 \%$ of Romanians believe in God, one of the largest percent of the countries from Center and Eastern Europe surveyed, after Georgia (99\%) and equality to Armenia (95\%) and Moldova (95\%). Also, according to the same study $44 \%$ of Romanians pray daily and only $1 \%$ of the Romanian adults identify as atheists. Based on these data, it is correct to say that Romanians are deeply religious individuals.

Meanwhile, politics, backed by media and, more recently, social media, have made religion a real tool for attracting the target audience. Religion and its relationship with technology, especially the way that technology influences religion and, in particular, religious message, has been a research problem in the last years. Christopher Helland (2000) made the difference between online religion, in which case the religious activity actually occurred in the online environment and religion online, in which case the internet was used as a tool to facilitate religious activity in the offline space.

Recent papers on the link between social media and religion paid a particular attention to the role of social media in developing religious values and improv- 
ing social values. Lim and Putnam in their article Religion, social networks and life satisfaction state that social networks provide powerful evidence for how social and participatory mechanisms shape the impact of religion on the satisfaction of life (Lim, Putnam, 2010). Zviadadze also points out that increased religiosity is manifested not only in traditional forms (participation in services, observance of rituals), but also through the expression of religion through new means of communication (videos with priests on YouTube, displaying a photo of a church as a desktop photo, etc.) (Zviadaze, 2014, 164-194).

The religious messages of either church members, politicians or simple citizens have increasingly found their place on Facebook. Faimau and Behrens (2016) show that Facebook - the most powerful social media network nowadays - is as one of the digital devices with the capacity to mediate religious behaviors, interactions and discourses. Also, Facebook is an "expressive medium" where people can both give and receive spiritual support, expressing beliefs and, at the same time, can receive spiritual guidance, religious resources and entertainment (Brubaker, Haigh, 2017 , 8). The same authors state that the relationship between religion, spirituality, and Facebook, is a reciprocal and mutually beneficial relationship.

\section{Political Communication and Online Political Engagement}

Political communication is similar to the deliberate transmission of a message with political content, directed to a target audience. Political communication covers the construction, sending, receiving, and processing of messages with direct or indirect impact on politics. The message can be send by politicians, journalists or citizens (Graber, Smith, 2005, 479). Political communication can be analyzed both in the instrumental aspect and in the institutional perspective, according to Camelia Beciu (2002). The author addresses the integrated political communication act, starting from "intentional relationship", "strategic position", "interaction space," the evolution of technology that "stakes" politics. This whole set of regulations give political communication a multidimensional valence.

Other authors also characterize political communication through interaction (Wolton, 1998, Norris, 2004). Pippa Norris states that political communication is an interactive process between politicians, the news media and the public, that operates down-wards from governing institutions towards citizens, horizontally among political actors and upwards from public opinion towards authorities (Norris, 2004).

Along with new technologies and new world events, political communication is a vast field "criss-crossed by the media" with various forms of associations and networks, actors, communicative contexts and styles, cultural frameworks and power relationships (Dahlgren, 2004, 17). Also, political communication is a largely mediated communication, mainly by journalists through traditional and online media (McNair, 2011). 
Politicians transmit messages through mass media or through other tools with the main purpose to achieve a positive relationship with the public opinion (Rusu, 2002, 31-32). Camelia Beciu summarizes the elements of political communication and analyzes in detail the network of interactions concerning the field: institutions and actors with different resources, projects and legitimations; processes, interactions and relationships that have certain configurations and a certain social impact (Beciu, 2002, 16).

Phillipson, Graham and Morgan (2004) argue that the concept of social network is both seductive and intuitively simple because there are few true isolates in the world. In essence, most of the people can be linked in different ways to other people who in their turn are linked to others (Phillipson, Graham and Morgan, 2004, 2). Aggarwal defines social networks as "a network of interractions or relashionships," (Aggarwal, 2011, 2) and Boyd and Ellison (2007) affirm that social network sites allow individuals to "(1) construct a public or semi-public profile within a bounded system, (2) articulate a list of other users with whom they share a connection, and (3) view and traverse their list of connections and those made by others within the system'.

Citizens' participation in political activity is a set of acts, actions, facts, through which they satisfy their ideological, moral or take a certain attitude in society to determine the political factors to act to meet some needs. Citizens' involvement and participation in political life aims to harmonize political decisions with people's values or needs and to determine politics to take into account these concerns and aspirations. When we refer at political participation we understand all forms of involvement in which citizens express their political opinion and some of the most innovative forms of political participation in the past decade are concerning the use of online communication tools. However, the researchers have not reached an agreement about the impact of online communication on citizens' civic and political engagement (Vissers, Stolle, 2014). Some researchers spoke about the limited effect of Internet on mobilizing new participants (Boulianne, 2015, Christensen 2011), while other papers highlighted the positive influence of the internet on political participation (Lee et al., 2013), even the fact that the internet could lead to a gender equality concerning participation (Sheppard, 2015).

Does online communication mobilize or normalize political participation? Reflections on the controversy over the mobilization or normalization of political participation as consequence of the internet use are found in the conclusions of the studies conducted by Fadi Hirzalla, Liesbet van Zoonen and Jan de Ridder (2011). The authors recall that the literature identifies two conclusions about the political use of the Internet. On the one hand, there are conclusions that the use of the Internet can lead to mobilization in terms of political participation of users, focusing on the political potential of the Web. On the other hand, there are conclu- 
sions that employed and active citizens mainly use political internet applications, thus normalizing political participation. The above mentioned authors argue that mobilization theses tend to focus on online events in specific cases and fit youngsters, while normalization theories are based on evaluations of general patterns of internet use and fit older people (Hirzalla, van Zoonen, de Ridder, 2011, 1-15).

When the audience actively participates in political communication, they begin to feel the power as involved citizens, whose opinions are to be taken into consideration. Thus, cyberspace transforms citizens from passive participants, spectators, into players and policy contributors with individual views (Effing, van Hillegersberg, \& Huibers, 2011). In social media, politicians need to be more accountable in their actions because citizens using new media have the opportunity to comment and question their doings. Responsibility in online reciprocity with citizens is of great importance as the degree and importance of interaction increases if the political leader answers users (Heiss, Schmuck, \& Matthes, 2018).

Social media are used by politicians for symbolic actions in their favor. The quantitative dimension of social networking friends, the number of online supporters, can be interpreted as a sign of popular sympathy and political support (Momoc, 2014, 165). Citizens participate in communication, comment, appreciate, distribute or take an attitude, discuss online themes. Analyzing the amateur electoral marketing, customized in a Digital Gherila, Momoc concludes that online space is perceived in our country both as a "channel of discharging the collective and personal frustrations and failures" as well as a virtual space for the projection of the political image, depending on the beliefs or political affiliation of the users (Momoc, 2014, 172).

After analyzing different concepts about social networks and studies in the field, we can conclude that online social networks are true bridges between citizens and politicians, a communication space in continuous expansion.

\section{Women's involvement in political life}

As far as feminism is concerned today, there is no simple and concise definition covering all aspects of the term. The term "feminism" appeared after a good deal of time after women started questioning their inferior status to men and asking for a better social position. Also, the term was not adopted immediately by those who militated for women's rights (Freedman, 2001, 3).

Researchers in the field have tried to outline feminist and gender theories over time. Rosemarie Tong in Feminist Thought: A Comprehensive Introduction (1989), studies the oppression of women, tries to explain the causes and consequences of it, and prescribes strategies for the empowerment of women. Feminism is "a defensive and offensive reaction to misogynism and sexism" (Miroiu, 2004). Feminism movement also relates to political commitment of women that has become 
a necessity for the eradication of gender-based injustice (Miroiu, 2004). Likewise, there are views that speak about feminism as a social movement par excellence that aims to change the position of women and who takes form into a political movement - the self-organization of women's politics (Delmar, 1986). Researchers like Cucklanz (2016) argue that feminist theory should not include only the interplay of gender and power, but also other elements like race, sexuality religion and ethnicity.

Because of women's activism in the last century, gender-related changes, changes in laws and policies in many areas have taken place in every region of the world: violence against women, family law, and women's access to political power, maternity leave and paternity leave. Women are now politically important: they are voters, taxpayers and bearers of the next generation of workers, voters and taxpayers. An equity agenda is being promoted more and more by women who are elected in political and public positions or by so-called "femocrats" (Orlof, Palier, 2009). Feminist political thinking has led to political, social or legislative changes that have improved equal opportunities, recognized the right to vote, equal pay under equal working conditions, legalization of abortion, support for victims of domestic violence and much more.

In the last 30 years, the theories of equality struggle have experienced a real development, with emphasis on equality between women and men in politics. There are two major arguments, which support the need for women to be represented in politics and gender balance. The first argument is that women account for about half of the population, so they should be represented equally in political life. However, this does not happen because of intentional discrimination or insufficient reconciliation of private life with the career or the job, and because of the male standards that still govern policy rules. The second argument relates to the fact that men-dominated politics leans too little on the needs and concerns of women who have specific experiences and common needs. Therefore, three major questions arise: 1 . How specific are the interests and concerns of women? 2. Men can or cannot represent the interests of women as well? 3. If there will be more representatives in their turn in politics, will their interests be better represented? (Phillips, 1998, 234).

As far as Romania is concerned, an important step in reducing the gender inequality was the accession to the European Union. The inequalities between women and men that actually existed in Romania were long reported before civil society, together with associations that defended women's rights, the process of negotiation prior to accession to the European Union was the factor that stimulated public institutions to address equality issues gender.

After the fall of communism in 1989, the presence of women in politics manifested a weak number in all the countries of the former Soviet bloc. This, partly 
due to the rejection of egalitarianism forced by the old regime through propagan$\mathrm{da}$, which led to a return to the values known before the establishment of the communist regime and to the development of a modern patriarchy (Miroiu, 2004, 230).

Once feminist movements evolved and women began to gain public and political positions, the researchers were interested in the similarities and differences between the two types of leadership: feminine and masculine. An early research from Eagly and Johnson (1990) showed that leadership styles were slightly gender stereotypic. For example, concerning the interpersonal comparisons, women were more interpersonally oriented and concerning the democratic versus autocratic comparisons, women were more democratic. The authors concluded that previous research who showed that women and men lead in the same way should be very much reviewed, just as the point of views that women and men have distinct gender styles also require review.

Similarly, Eagly et al. (2000) show that agentic characteristics can be found more in male leadership: assertive, controlling, ambitious, independent, competitive style, while communal attributes can describe better women leadership: concern with the welfare of other people (helpful, sympathetic, nurturing etc.). Another interesting finding is that leaders adapt their style based on people's expectation, categorizing them as male or female (Eagly, Johannesen-Schmidt, 2001). Although the researchers do not agree yet how gender influence the way people lead, it is clear that leadership style depends not only on gender, but on other factors like educational and cultural background, personality and life and work experience.

\section{Methodological design}

In the context described above - the explosion on religious messages on social media and Facebook in particular, the increasing involvement of women in political life and the special case in which Bucharest, the capital city of Romania, has the first woman mayor - this study analyzes quantitatively the messages of mayor Gabriela Firea on Facebook during a normal mandate period.

This study covers messages from Gabriela Firea's Facebook page and was conducted between the 1st of July and the 31st of December 2018 on quantitative criteria. Gabriela Firea is the first woman mayor of the Romanian capital city, elected by direct vote in 2016 .

The analysis period was chosen for two reasons. The first reason is that in July 2018 have passed two years of the mayor's mandate. The second reason is that most of the research in the field focuses on the analysis of online political messages during electoral campaign times, and it seemed important to investigate how the mayor communicates, especially religious messages, during a normal period of office. 
The objectives of this study were to identify the use of religious messages by the mayor Firea in social media and the types of reactions and interactions of the public.

Therefore, the research questions of the present study are, as follows:

Q1. How does mayor Gabriela Firea uses social media for promoting religious messages?

Q2. How does the public of the Facebook page of mayor Gabriela Firea reacts at and interacts with religious posts?

\section{Results}

In the Romanian political landscape, the mayor of Bucharest, Gabriela Firea, is one of the women politicians who, with the public ascension, reiterated her beliefs on several channels of communication: either in TV appearances or during discussions with citizens, and, more recently, through the messages on her Facebook page. The affirmation of faith is, for Gabriela Firea, one of her political communication strategies for the purposes of humanization, bringing her closer to the simple voter, with fear and faith in God. Also, apart from the fact that she is the first woman mayor of Bucharest, the Facebook page of Gabriela Firea is ranked third in the top of the most popular Facebook pages of Romanian politicians (IQads, 2018), after President Klaus Iohannis and former Prime Minister Victor Ponta. Gabriela Firea has 490.327 fans.

As for the descriptive quantitative analysis, mayor Gabriela Firea posted 154 messages on her Facebook page, messages in which the author of the present study identified the following major themes: Health, Education, Policy / Public Administration Official, Social, Religion / Culture, Youth / sport, Transport / Environment, Tourism, Projects / Infrastructure, Family / Personal. The analysis of the mayor's posts Firea strictly targeted the text messages and did not approach the accompanying photos or videos.

Most religious-themed messages were posted in December 2018, which can be explained by the frequency of Christian holidays in this period, and the fewest messages related to faith were posted in July.

The distribution of monthly posts and topics can be seen in the figure below (Figure 1).

Overall, during the analyzed period, Gabriela Firea published 154 messages. Most of the posts were political and administrative, 25, followed by health, 24, and those with cultural and religious themes - 23. At close distance, 21 family related messages follow them. At the opposite end, the fewest posts refer to tourism, 2, the youth theme is present in only 5 of the mayor's messages, the education is mentioned in 6 posts and the official meetings in 8 messages. Also, Gabriela Firea addresses the social themes in 9 messages, the projects / the infrastructure of the 


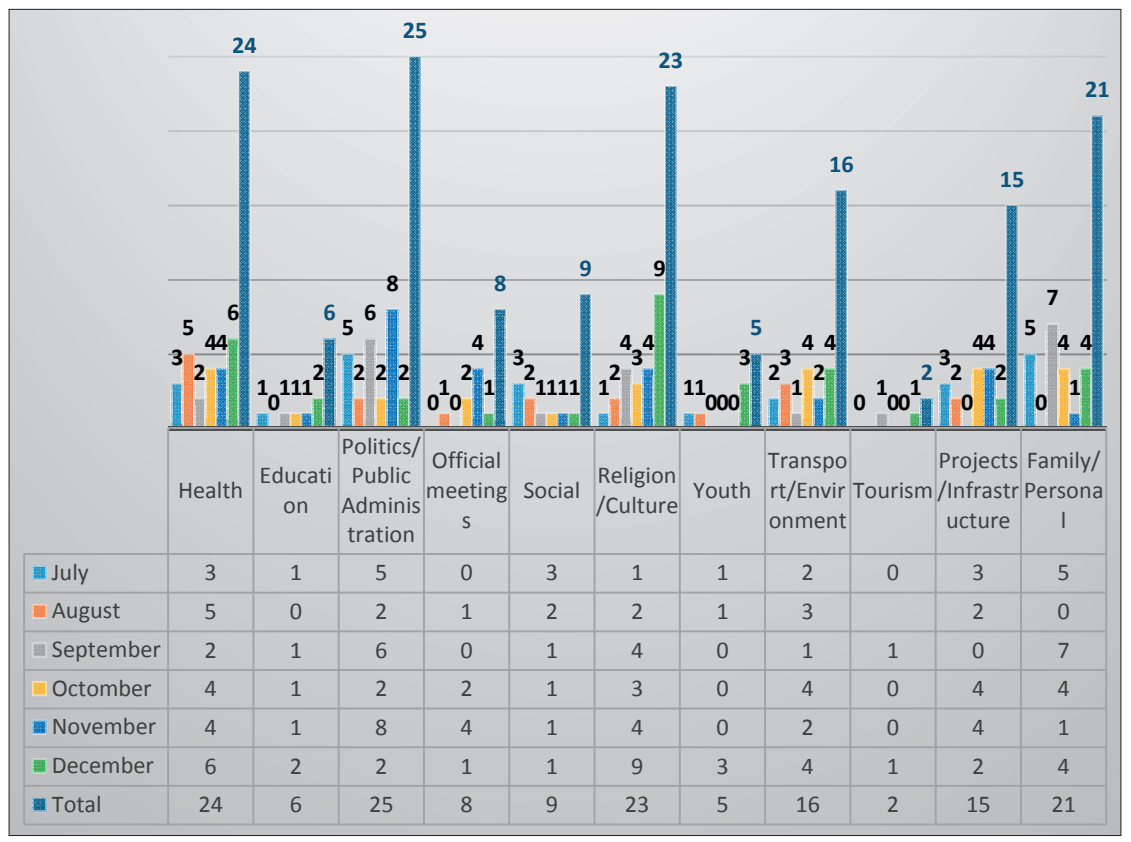

Figure 1. Distribution of Gabriela Firea's posts on themes and months, 1st of July - December 31, 2018

city in 15 messages and environment related topics in 16 messages. It should be noted that family-related posts occupy a significant number of all messages, at a close distance from cultural-religious ones.

Regarding the share of cultural-religious posts, they occupy $23,15 \%$ of all messages transmitted via Facebook by Gabriela Firea.

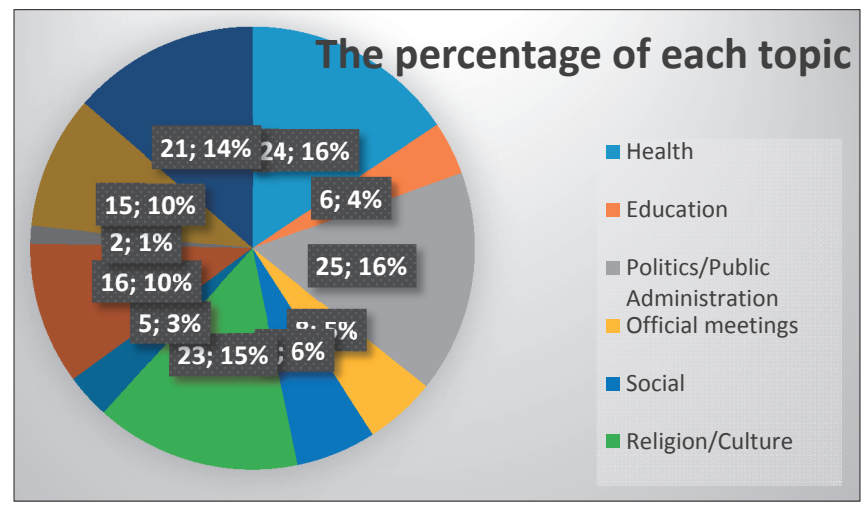

Figure 2. The approached topics

The Mayor has 23 cultural-religious messages in the analyzed period, from which 15 messages with exclusively religious content. The quantitative analysis 
focused on quantifying the reactions, comments and shares of the 15 identified religious messages.

For the quantification of the reactions, the analysis has totalized both the number of reactions at the original post on Firea 's Facebook page and the number of reactions on the distribution (shares) of the post on the pages of his fans. Similarly, for the quantification of comments, this study has totalized both the number of comments on the original post and the number of comments on the distribution (shares) of the post on the pages of his fans.

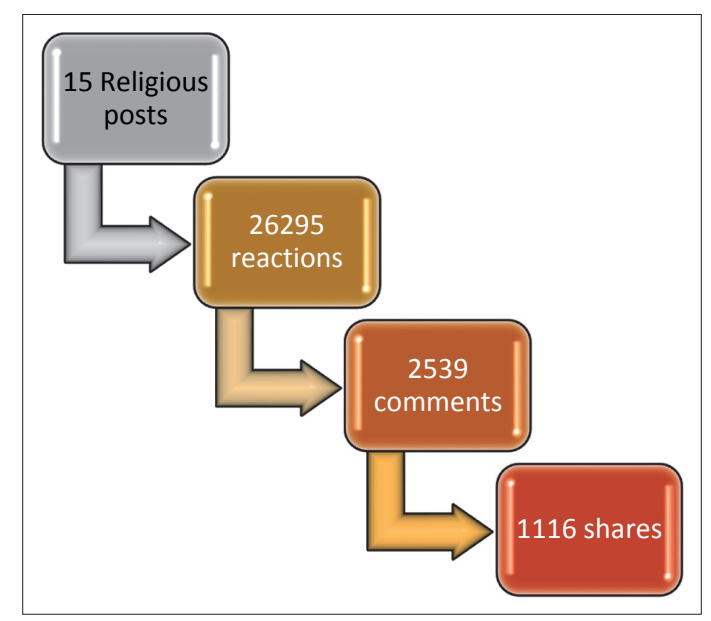

Figure 3. Reactions, comments and shares of religious posts

Therefore, the 15 religious posts of the Gabriela Firea totalized 26.295 reactions. Correspondingly, 2.539 comments and 1.116 shares is an impressive number of interactions.

The following table (Table 1) shows the reactions to each religious post, as well as their negative or positive typology. As positive reaction, the analysis took into account the first four emoticons available on Facebook and as negative reaction, the author recorded the last two emoticons.

Analyzing the number of reactions that Gabriela Firea has on posts on her Facebook page during the aforementioned period, it appeared that the message with the most responses, 10.845, from the Mayor's followers, is the Christmas message published on December 25, 2018, a message of religious content: "Happy Christmas, dear friends! Be healthy and have your loved ones near you! Let it be good and be blessed by the Child Jesus! \#CentenaryChristmas". It is also the message with the most comments -1.371 and most distributions - 333. It is also worth mentioning that the photo used by the mayor to illustrate the message is a photo with her family.

On the contrary, even the celebration of the National Day of Romania, message posted on the 1st of December, an important holiday for citizens, failed to collect 


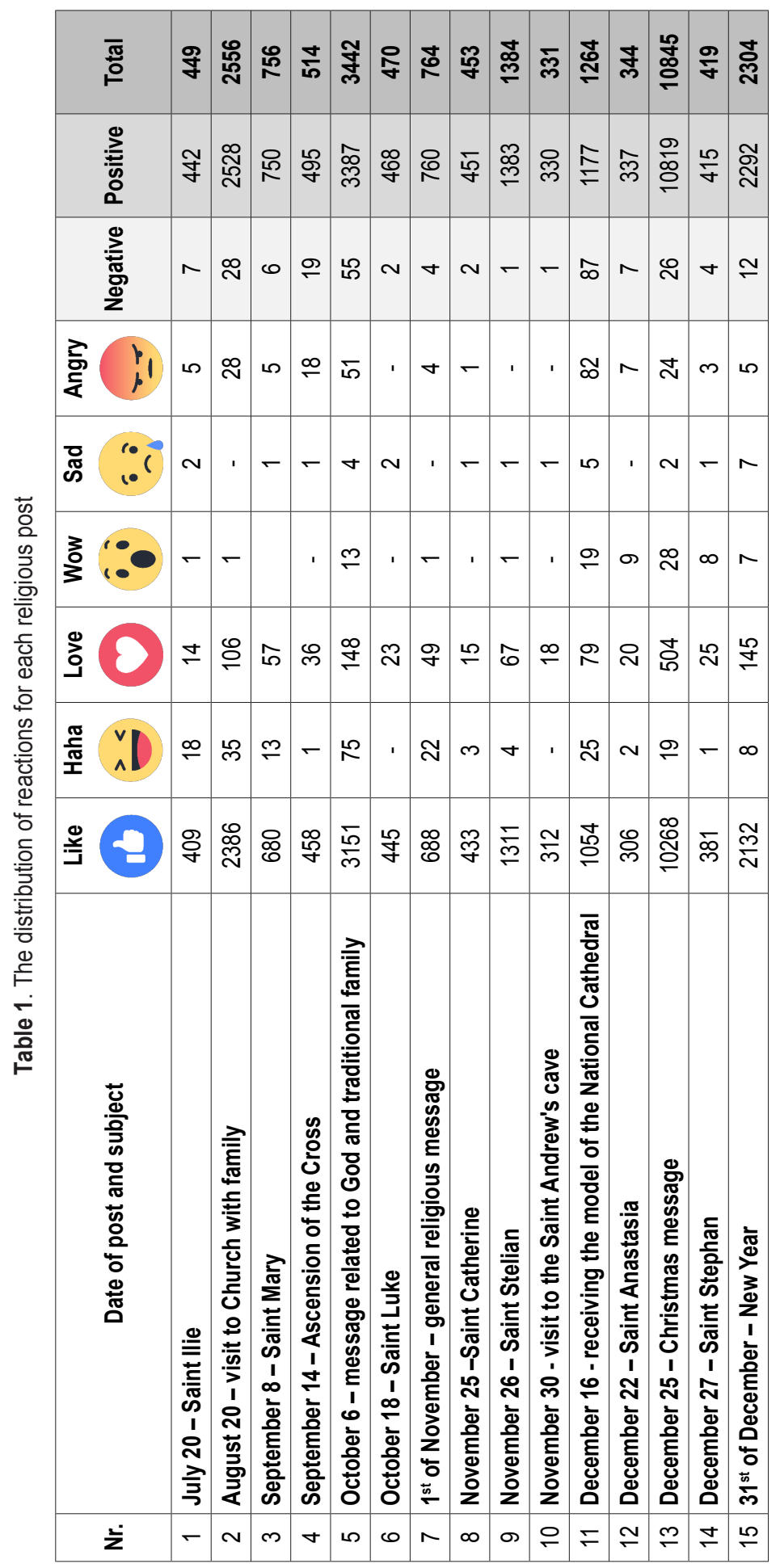


such a large number of comments and shares (only 103 comments and 142 shares). As well, on the opposite side, a message from other category (education) posted on December 17 about "The Educational Infrastructure Development Program - No School with a 3-shift program", has only 225 responses from the Facebook page fans.

Regarding the responses to the 15 religious messages, the messages transmitted during the celebration of Saints have the fewest reactions, e.g., the message on St. Stephen's Day - 419 reactions, the message on St. Catherine's Day - 453 reactions, the message on St. Luke's Day - 470 reactions, while other more personal religious messages, like the one posted on October 6, thankful for family life - 3.442 reactions, or the one on December 16 announcing that she received from the Patriarch a crystal model of the National Cathedral - 1.264 reactions, make the followers of the page respond and comment more.

Another finding of this study is that the religious messages of Gabriela Firea from the analyzed period have an overwhelming number of positive reactions and fewer negative reactions.

Therefore, from 26.295 reactions at the Mayor religious posts $99 \%$ are positive. This means that Gabriela Firea has a successful online communication concerning the religious theme and that the audience endorse her religious messages. Also, we can assume that the users would like to see more similar content.

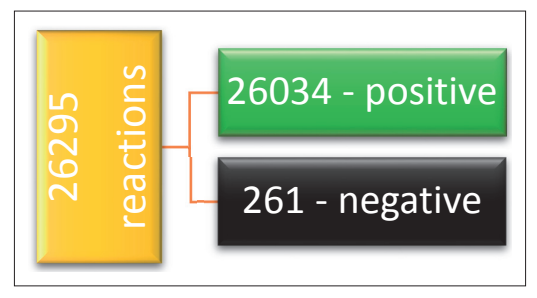

Figure 4. Positive and negative reactions

Regarding the comments and shares, the table below shows their evolution from one post to another and also the types of comments (neutral-positive or negative) for each message.

The Christmas message has the greatest number of shares, 333, followed by Saint Stelian message, 213, and the message published on October 6 about family and God, in the context of the national referendum for redefining family in Romania's Constitution - 112. The opposite as number of shares is the message regarding a visit to the Saint Andrew's cave -9 shares.

The most commented post was the Christmas message with 1.371 total comments, followed by the New Year's message with 413 comments and the message about family and God with 212 total comments. The least commented post is the 
Table 2. Distribution of comments and shares for each religious post

\begin{tabular}{|c|c|c|c|c|c|c|}
\hline Nr. & Date of post and subject & 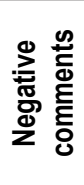 & 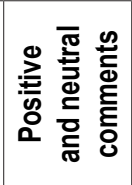 & 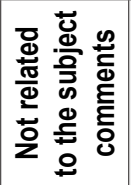 & 휼 & 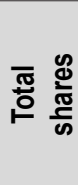 \\
\hline 1 & July 20 - Saint llie & - & 15 & 2 & 17 & 28 \\
\hline 2 & August 20 - visit to Church with family & 6 & 93 & - & 99 & 71 \\
\hline 3 & September 8 - Saint Mary & 12 & 52 & - & 64 & 31 \\
\hline 4 & September $14-$ Ascension of the Cross & - & 41 & 12 & 53 & 14 \\
\hline 5 & October 6 - message related to God and traditional family & 122 & 57 & 33 & 212 & 112 \\
\hline 6 & October 18 - Saint Luke & - & 21 & - & 21 & 42 \\
\hline 7 & $1^{\text {st }}$ of November - general religious message & - & 72 & 5 & 77 & 51 \\
\hline 8 & November 25 -Saint Catherine & - & 14 & - & 14 & 60 \\
\hline 9 & November 26 - Saint Stelian & - & 45 & 5 & 50 & 213 \\
\hline 10 & November 30 - visit to the Saint Andrew's cave & - & 18 & 1 & 19 & 9 \\
\hline 11 & December 16 - receiving the model of the National Cathedral & 4 & 72 & 2 & 78 & 31 \\
\hline 12 & December 22 - Saint Anastasia & - & 24 & 3 & 27 & 31 \\
\hline 13 & December 25 - Christmas message & 21 & 1345 & 5 & 1371 & 333 \\
\hline 14 & December 27 - Saint Stephan & - & 21 & 3 & 24 & 27 \\
\hline 15 & $31^{\text {st }}$ of December - New Year & 1 & 410 & 2 & 413 & 63 \\
\hline
\end{tabular}

message from November 25 about Saint Catherine with only 14 comments. As the data show, most negative comments are at family and God related post from the 6th of October, 122 negative comments, in the context of the referendum. This can easily be explained by the public debate created between supporters of the traditional family and those of the modern family. In few words, the referendum sought to introduce in the Romanian Constitution the phrase that marriage is available between a man and a woman. If the referendum passed the voting, same-sex marriages would have become impossible in Romania.

As it emerged from the analysis, from a total of 2.539 comments, over $90 \%$ of them are positive and neutral. Their total distribution by category can be seen below (Figure 5).

Likewise, the analysis revealed that 73 comments are not related to the published message, but to the administrative problems of the inhabitants of Bucharest, such as the summer mosquito invasion, the rehabilitation of the streets or the blocks. Another observation would be that much of the negative comments are written by the same people each time. We can suppose that these users are either sympathizers of other political people or parties, either vehemently dissatisfied citizens of the Mayor's activity, with intense activity on Facebook, which reserves special time to negatively comment most posts. 


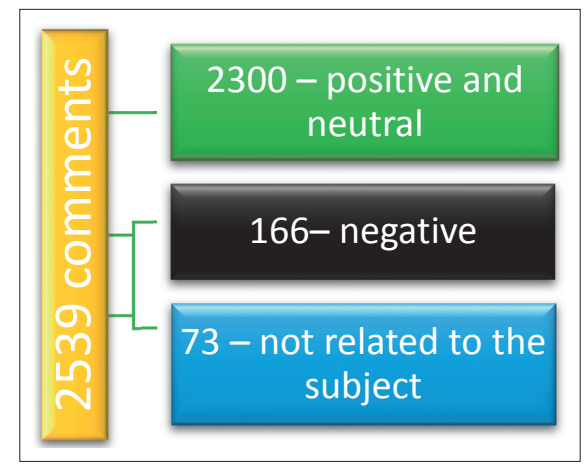

Figure 5. Categories of comments

Another observation that emerges from Gabriela Firea's analysis of religious messages on Facebook is that the Mayor does not post at every major Christian holiday, but especially when it is connected with one of the family members or when the Saint celebrated has a connection with her family or home, such as St. Stelian, the child and family protector. Otherwise, the connection between faith and family is evident in most of Gabriela Firea's posts, the family representing for the woman politician the cradle of faith and of her formation as a Christian. Notable in this regard is the post made on the October 6, 2018: "We thank God for all our lives, for our parents and our children, our loved ones, for the beautiful moments spent together, the joy of looking at a sunrise or enjoying nature, flowers, clear sky."

\section{Discussions and conclusion}

Following the quantitative research of the messages posted by Gabriela Firea on Facebook, this paper states that expressing faith in God and the proximity to Christian values are some of the strengths of her communication strategy. Mayor Gabriela Firea uses social media to promote religious messages of three types:

- messages related to the celebration of certain Saints - many of them being related with family members,

- visits at holy places, along with family members most of the time

- general religious messages, thanking for what Divinity offered her.

From the analyzed data, it is obvious that the posts on her Facebook page, which focus on family-related religious topics, are among the most appreciated. As well as researchers argued that religious networks can facilitate volunteerism and civic engagement (McClure, 2015; Merino, 2013; Schwadel et al., 2015), this study revealed that the religious messages published by the Mayor of Bucharest on her Facebook page made her fans to commit and to interact positively concerning religious ideas and values that she promotes. This leads also to a certain civic engagement. 
Clearly, in the case of Gabriela Firea the relationship between her religion beliefs, spirituality and Facebook is a reciprocal and mutually beneficial relationship, as Brubaker, and Haigh (2017) stated. According to theories that analyze political communication as a space of interaction (see Beciu, Wolton, Norris), described above, Gabriela Firea has found in Facebook a good environment to propagate messages related to spirituality, messages that many users interact with. As noted above, Gabriela Firea does not respond to the interactions and reactions on her Facebook page.

Like Effing, van Hillegersberg, \& Huibers stated in 2011, cyberspace and in our case Facebook, transforms citizens from passive participants, spectators, into players and policy contributors with individual views. The large amount of interactions and reaction to Firea's religious messages is a proof that users on her Facebook page are actively involved in commenting and disseminating her posts.

Like many politicians, Gabriela Firea uses Facebook for symbolic actions in their favor, as Momoc (2014) argued, especially by displaying her faith online. Also, in the spirit of the theory formulated by the same author, her large number of online fans and the number of the reactions and interactions from her Facebook page can be interpreted as a sign of popular sympathy and political support.

Additionally, analyzing the themes which predominates in posts on his Facebook page, highlighting those related to faith and family, Gabriela Firea can be described from the perspective of communal attributes which governs women leadership, as Eagle et al. (2000) stated. As evidenced by her online messages, as political leader she is sympathetic, helpful, nurturant, concerned with the welfare of others.

Summarizing, the above analysis has led to the verification of previously formulated hypotheses. Over the years, religion has played an overwhelming role in establishing public policies and social norms, so what Gabriela Firea does through her Facebook page, namely to display her belief in front of a profoundly Christian electorate, adds to her image. At a certain time, each of her constituents or voters are found in one of the religious messages she publishes: whether it is a day of name, or divine help received in case of illness, the confidence that divinity maintains a united family, visits to sacred places, or attending services at great Holydays. There are thoughts and actions that the simple man, politically uninvolved, has, and this brings Gabriela Firea closer to the citizens and humanizes her. The fact that her religious posts generated the greatest number of interactions only confirms that Mayor Gabriela Firea reaches her goal in attracting new fans and reward the existing ones. In other words, the Mayor of Bucharest uses religious messages to promote her political image and to gain the sympathy of the electorate.

In the analyzed period, religious posts with the most reactions and interactions were those in which Mayor Gabriela Firea links the religious message to family 
and personal situations. Therefore, the study verified that religious posts generate a large number of reactions and interactions. It is worth remembering that the message with the most reactions and interaction is her Christmas message, a religious - family linked one, who totalized 10.845 reactions and 1.371 comments. Noteworthy is that Gabriela Firea manages to have many positive reactions and interactions without personally interacting with the fans of her Facebook page.

Noteworthy is that the number of reactions, comments and shares to Gabriela Firea's religious posts is slightly fluctuating. During data collection, the author of the present study learned that from one month to the next, some users may withdraw their reaction, delete comments or shares or, at the same time, they may appreciate some posts after a long time since they were published.

A future line of research could be the structure of the audience from Facebook page of mayor Gabriela Firea and the way user differently react. It is interesting to find out how many of those who appreciate, comment or share the posts are inhabitants of Bucharest and how many are watching and evaluating her online activity without being directly targeted by her policy. It might also be a question of how many of Bucharest's people appreciate or disapprove online her activity, compared to the fans of her Facebook page who are from the outside Bucharest. It is, also, interesting to investigate the percentage of personal and family messages on the Facebook page of mayor Firea, in relation to the political and administrative messages, as well as the reactions and interactions of the users to them. For future gender studies, also a line of research would be quantifying the number of male and female fans of a woman mayor, in our case Gabriela Firea, and the type of reactions and interactions that each category has on posts from different themes and periods.

\section{References}

1. Aggarwal, Charu C. (2011). Social Network Data Analytics, Springer Science \& Business Media, New York, NY.

2. Beciu, Camelia (2002). Comunicare politica, Editura comunicare.ro, București.

3. Bellin, Eva (2008), FAITH IN POLITICS. New Trends in the Study of Religion and Politics, World Politics, Cambridge University Press, 60(2): 315-347.

4. Boulianne, Shelley (2015). Social media use and participation: A meta-analysis of current research. Information, Communication \& Society, 18.

5. Boyd, D. M, Ellison, N. B. (2007). Social network sites: Definition, history, and scholarship. Journal of Computer-Mediated Communication, 13(1).

6. Brubaker, Pamela Jo, Haigh, Michel M. (2017). The Religious Facebook Experience: Uses and Gratifications of Faith-Based Content. Social Media + Society: 1-11.

7. Campbell, Heidi (2004). Challenges Created by Online Religious Networks. Journal of Media and Religion, 3(2). DOI: https://doi.org/10.1207/s15328415jmr0302_1. 
8. Campbel, Heidi (2010). When Religion Meets New Media. Media, Religion and Culture. 1st Edition, Routledge.

9. Campbell, Heidi (2011). Internet and Religion (pp. 232-250). In Robert Burnett, Mia Consalvo, Charles Ess (Eds.). The Handbook of Internet Studies, Blackwell Publishing.

10. Campbell, Heidi (2012). Understanding the Relationship between Religion Online and Offline in a Networked Society. Journal of the American Academy of Religion, 80(1): 64-93. DOI: https://doi.org/10.1093/jaarel/lfr074.

11. Carp, Radu (2013). Religie, politică E statul de drept. Secvențele unei acomodări, Editura Humanitas, Bucureşti.

12. Chaeyoon, Lim, Putnam, Robert D. (2010). Religion, Social Networks, and Life Satisfaction. American Sociological Review. DOI: https://doi.org/10.1177/0003122410386686.

13. Christensen, Henrik Serup (2011). Political activities on the Internet: Slacktivism or political participation by other means?. First Monday, 16: 2-7.

14. Cristea, Adriana Anca, Apostol, Mihaela-Simona, Dosescu, Tatiana (2015). The Role of media in Promoting Religious Tourism in Romania. Procedia - Social and Behavioral Sciences, 188: 302-306.

15. Cucklanz, Lisa (2016). Feminist Theory in Communication. The International Encyclopedia of Communication Theory and Philosophy: 1-11. DOI: https://doi.org/ 10.1002/9781118766804.wbiect157.

16. Dahlgren, Peter (2004). Theory, Boundaries and Political Communication: The Uses of Disparity. European Journal of Communication, 19(1): 7-18.

17. Delmar, Rosalind (1986). What Is Feminism: A Re-Examination. In Juliet Mitchell and Ann Oakley (Eds.). What Is Feminism?. New York: Pantheon.

18. Effing, R., van Hillegersberg, J., \& Huibers, T. (2011). Social Media and Political Participation: Are Facebook, Twitter and YouTube Democratizing Our Political Systems? (pp. 25-35). In E. Tambouris, A. Macintosh, \& H. de Bruijn (Eds.), Electronic Participation, Springer, Berlin-Heidelberg.

19. Eagly Alice, Johnson Blair (1990). Gender and Leadership Style: A Meta-Analysis. Psychological Bulletin, 108(2): 233-256.

20. Eagly, A. H., Wood, W., \& Diekman, A. B. (2000). Social role theory of sex differences and similarities: A current appraisal (pp. 123-174). In T. Eckes \& H. M. Trautner (Eds.), The developmental social psychology of gender. Mahwah, NJ: Erlbaum

21. Eagly, A. H., Johannesen-Schmidt, M.C. (2001). The Leadership Styles of Women and Men. Journal of Social Issues, 57(4).

22. Evans, Jonathan, Baronavski, Chris (2018). How do European countries differ in religious commitment? Use our interactive map to find out. Retrieved from http://www. pewresearch.org/fact-tank/2018/12/05/how-do-european-countries-differ-in-reli gious-commitment/ on January 2019.

23. https://www.facebook.com/gabifirea/ 
24. Faimau, G. \& Behrens, C. (2016). Facebooking religion and the technologization of the religious discourse: A case study of a Botswana-based Prophetic Church. Online Heidelberg Journal of Religions on the Internet, 11(1): 66-92.

25. Fox, Jonathan (2018). An Introduction to Religion and Politics: Theory and Practice, Second Edition, Routledge.

26. Freedman, Jane (2001). Feminism, Open University Press, Buckingham, Philadelphia.

27. Gill, Anthony (2001). Religion and Comparative Politics. Annual Review of Political Science, 4: 117-138.

28. Giorgi, Alberta, Polizzi, Emanuele (2014). Paths of Research in Religion and Politics: An Introduction. The Open Journal of Sociopolitical Studies, DOI: DOI: 10.1285/ i20356609v7i1p01.

29. Graber, Doris, Smith, James (2005). Political Communication Faces the 21st Century. Journal of Communication, 55(3): 479-507.

30. Haynes, Jeff (2014). Religion in Global Politics, Routledge, New York, First published 1998 by Pearson Education.

31. Helland, C. (2000). Online Religion/Religion Online and Virtual Communitas (PP. 205-224). In Jeffery K. Hadden and Douglas E. Cowan (Eds.), Religion on the Internet: Research Prospects and Promises. JAI Press: New York.

32. Helland, C. (2012). Scholar's top 5: Christopher Helland on online religion and religion online (Network for New Media, Religion and Digital Culture Studies). Retrieved from http://digitalreligion.tamu.edu/blog/mon-05142012-1132/scholar\%E2\%80\%99 s-top-5-christopher-helland-onlinereligion-and-religion-online on January 2019.

33. Heiss, R., Schmuck, D., \& Matthes, J. (2018). What drives interaction in political actors' Facebook posts? Profile and content predictors of user engagement and political actors' reactions. Information, Communication \& Society, 1-17. DOI: https://doi.or g/10.1080/1369118X.2018.1445273.

34. Hirzalla, Fadi, van Zoonen, Liesbet, de Ridder, Jan (2011). Internet Use and Political Participation: Reflections on the Mobilization/Normalization Controversy. The Information Society Journal, 27(1).

35. Johnstone, Ronald L. (1975). Religion and Society in Interaction: The Sociology of Religion. New Jersey: Prentice.

36. Kirkpatrick, L. A. (2005). Attachment, evolution, and the psychology of religion. New York, NY: Guilford Press.

37. Lovheim, M. (2004). Intersecting identities: Young People, Religion and Interaction on the Internet, Uppsala: Uppsala University

38. Lee C., Chen D., Huang T. (2013). The Interplay Between Digital and Political Divides: The Case of E-Petitioning in Taiwan. Social Science Computer Review, no. 32.

39. McClure, J.M. (2015). The Cost of Being Lost in the Crowd: How Congregational Size and Social Networks Shape Attenders' Involvement in Community Organizations. Review of Religious Research, 57: 269-286. 
40. McNair, Brian (2011). An introduction to political communication. Fifth edition, Routledge.

41. Merino, S.M. (2013). Religious Social Networks and Volunteering: Examining Recruitment via Close Ties. Review of Religious Research, 55: 509-527.

42. Miroiu, Mihaela (2004). Drumul către autonomie. Teorii politice feministe, Editura Polirom, Iaşi.

43. Momoc, Antonio (2014). Comunicarea 2.0. New media, participare și populism, Editura Adenium, Iași.

44. Neuhaus, Richard John (1986). The naked public square: Religion and Democracy in America 20, 2nd Edition, Wm. B. Eerdmans Publishing Company, Michigan.

45. Nietzsche Friedrich Wilhelm (2011). The Antichrist, Editura Antet, (first published in 1895).

46. Norris, Pippa (2004). Political Communication. Encyclopedia of the Social Sciences. Retrieved from https://sites.hks.harvard.edu/fs/pnorris/Acrobat/Political\%20Communications\%20encyclopedia2.pdf accessed January 2019.

47. Norris, Pippa, Inglehart, Ronald (2004). Sacred and Secular: Religion and Politics Worldwide, Cambridge: Cambridge University Press.

48. Olrof, Ann Shola, Palier, Bruno (2009). The Power of Gender Perspectives: Feminist Influence on Policy Paradigms. Social Politics 16(14).

49. Pew Research Center (2017). Religious Belief and National Belonging in Central and Eastern Europe. National and religious identities converge in a region once dominated by atheist regimes. Retrieved from http://assets.pewresearch.org/wp-content/uploads/ sites/11/2017/05/15120244/CEUP-FULL-REPORT.pdf January 2019.

50. Phillipson, Chris, Allan, Graham and Morgan, David (2004). Social Networks and Social Exclusion: Sociological and policy perspectives, Ashgate, Aldershot.

51. Phillips, Anne (1998). Feminism and Politics, Oxford Universitz Press, New York.

52. Rusu, Flavius Călin (2002). Introducere în Ştiinţa Comunicării şi a Relațiilor Publice, Editura Institutul European, Iași.

53. Sakellariou, Alexandros (2018). Believing in Participation: Youth, Religion and Civic Engagement (pp. 153-177). In Pilkington, Hilary, Pollock, Gary, Franc, Renata (Eds.), Understanding Youth Participation Across Europe. From Survey to Ethnography, Palgrave Macmillan.

54. Schilbrack, Kevin (2010). Religions: are there any?. Journal of The American Academy of Religion, 78(4).

55. Schwadel, P., Cheadle, J. E., Malone, S. E., Stout, M. S. (2015). Social Networks and Civic Participation and Efficacy in Two Evangelical Protestant Churches. Review of Religious Research. DOI: 10.1007/s13644- 015-0237-y.

56. Sheppard Jille (2015). Online petitions in Australia: Information, opportunity and gender. Australian Journal of Political Science, 50(3).

57. Stan, Lavinia, Turcescu, Lucian (2007). Religion and Politics in Post-Communist Romania, Oxford University Press, New York. 
58. Surugiu, Romina (2012). Media and religion in Romania. Three contexts and a discussion. European Journal of Science and Theology, 8(4): 205-213.

59. IQads (2018), The top of Romanian politicians on Facebook. Retrieved from https:// www.iqads.ro/articol/43034/topul-politicienilor-romani-in-social-media on December, 2018.

60. Tenzer, Nicolas (1994). Philosophie politique. Paris: PUF.

61. Tong, Rosemarie (1989). Feminist Thought: A Comprehensive Introduction, First Edition, Routledge, London.

62. Vissers, Sara \& Stolle, Dietlind (2014). The Internet and new modes of political participation: online versus offline participation. Information, Communication and Society Journal, 17(8).

63. Wolton, Dominique (1998). Penser la communication, Version poche, Champs, Flammarion.

64. Weber, Max (1998). Sociologia religiei, Editura Teora, Bucureşti, 1998.

65. Zviadaze S. (2014). I "like" my Patriarch. Religion on Facebook. New forms of religiosity in Contemporary Georgia. Heilderberg Journal on Religions on the Internet, 6(1). 